International Journal of Advanced Biological and Biomedical Research Available online at http:www.ijabbr.com

Volume 7, Issue 3 (2019) pp. 274-286

Original Article

\title{
Growth Performance and Profitability of Broilers with Vermi Meal on Fermented Ration Under Two Management Systems
}

\author{
Marcos Erram Bollido
}

Department of Agriculture and related Programs Instructor II, Northwest Samar State

University Barangay Erenas, San Jorge, Samar, Philippines

*Corresponding Author E-mail: markbollido@yahoo.com

Received: 26 March 2019, Revised: 6 May 2019, Accepted: 17 May 2019

\begin{abstract}
This study was conducted to evaluate the effects of the different levels of vermi (Eisenia fetida) meal on fermented ration in broiler chicken growth and profitability under two management systems. For this purpose, 120 day old broiler chickens (cobb vantress) were tested in a completely randomized design with four (4) dietary treatments: first, the commercial feeds (control), second, $2 \%$ vermi meal+local ingredients, third, $3 \%$ vermi meal+local ingredients and fourth, 5\% vermi meal+local ingredients in three (3) replications where 15 broilers were randomly distributed in the pens. The result revealed that the total confinement system had higher body weight and weight gain with a slight difference of 35.60 grams and 36.90 grams respectively as compared to that of free- range system that had lesser feed consumption with difference of 81.10 grams and high in net income and Return of Investment (ROI). In relation to feed ration, feed consumption increased when given higher percentage of vermi and it was significantly different from the commercial feeds. In three (3) different levels of vermi meal, though they didn't have significant difference to each other, the $2 \%$ level of vermi meal was comparable to commercial feeds and showed a difference in terms of body weight of 296.70 grams in TC; 326.00 grams in FR. In terms of weight gain 296.67 grams in TC and 370.97 grams in FR in both management systems. Consequently, $2 \%$ level vermi meal had an optimum result in final body weight, weight gain and high in feed conversion.
\end{abstract}

Key words: Vermi, Free range, Total confinement, Profitability, Fermented ration.

\section{Introduction}

Broiler chickens (Gallus gallus domesticus), or broilers, are gallinaceous domesticated fowls, bred and raised specifically for meat production. They are a hybrid of the egg-laying chickens, both being subspecies of the red jungle fowls (Gallus gallus). Typical broilers have white feathers and yellowish skin. Chicken broiler production is one of the most progressive animal enterprises in the Philippines today. The poultry industry began as a backyard enterprise but 
has shifted to the formation of very large integrated contract farming operations. (Kruchten, 2002).

The industry is largely dependent on protein feedstuffs which are imported at high cost. However, backyard raisers farmers resort to feeding their broilers with commercial feeds but not appropriate to the ages of their birds due to limited capital to purchase the feeds needed. Likewise due to the scarcity of imported sources of protein and the difficulty of acquiring animal protein feeds from wholesalers. This feeding system definitely gives a ration which does not meet the nutrient requirements of broilers (Ravindran \& Blair, 1993).

The substitution of dry vermi meal for fish meal lowers the cost of diet production which is an indication of a more cost efficient and cheaper non-conventional ingredient in relation to the fish meal. Consequently, the farmer will benefit economically through the utilization of this cheaper ingredient at 7.5 to $25 \%$ inclusion of dry vermi meal to raise $\mathrm{H}$. longifilis without reduction in specific growth rate (Sogbesan et al., 2007).

(Bahadori et al., 2014) used of 2\%,3\%,4\%, and 6\% Eisenia fetida vermi meal on broilers showed that heart weight was not affected in none of the vermi meal percentage while the breast weight was only affected by $2 \%$ and $3 \%$ of the treatments.

Adding more than two (2) percent molasses can be achieved and most typical feed formulas can "absorb" up to six (6) percent molasses without problems. But, as molasses is quite rich in potassium, this may increase water intake (it depends on overall formula electrolyte balance) and lead to wet-litter associated problems.

It should be kept in mind that the protein quality in molasses is rather low as not all nitrogen present (used to determine crude protein) is actually bound into proteins. Usually, a moderate level of four (4) percent is preferred for the above reasons, assuming overall molasses quality is acceptable (Loannis, 2013).

(Elgilani, 2007), publicised that incorporation of molasses in broiler diets resulted in improved performance of the experimental birds with regard to all the productive parameters.

Another way is to alter the feeding management by using indigenous but nutritious feed ingredients rather than feeding them with costly commercial feeds. The use of indigenous feed ingredients like leaf meals from shrubs and trees, animal by-products and vermi meals are given emphasis in the animal industry at present (Ravindran \& Blair, 1993). Meta-analysis presented by (Sales, 2014), proved little evidence that a poultry production system with outdoor access has any impact on performance, carcass composition, and meat quality. Factors other than improved meat quality, such as those related to animal welfare, might be responsible for consumers' preferences for poultry meat from birds with access to pasture.

Further, birds reared on the floor appear less likely to harbor and shed Salmonella, as litter may serve as a seeding agent for competitive exclusion by other microorganisms (Özhan et al., 2016). Vermi utilization is very limited in Samar province and even in the Philippines as a whole hence, this study is proposed.

\section{Objectives of the Study}

This study aimed to determine the growth performance and profitability of broilers raised under two management systems with vermi meal supplementation in their diet, specifically to:

1. determine the growth performance of broilers with vermi meal supplementation in their diet raised under free- range and in total confinement system in terms of:

a) body weight,

b) weight gain, 
c) feed consumption,

d) feed conversion ratio (FCR),

e) water consumption, and

f) dressing percentage;

2. calculate the production, profitability and the return of investment of broilers raised under two management systems and with vermi meal supplementation;

3. measure the level of vermi meal incorporation in the feed for broiler growth and profitability performances; and

4. compare the interaction of the levels of vermi meals in the diet of the broilers with the two management systems of raising.

\section{Materials and methods}

\section{Housing of the experimental birds}

Brooding cages both for free range and total confinement were separately made. Growing cages for total confinement birds and areas for free-range group of broilers were prepared following the caging and area density requirements. Free Range requires 2.4 sq. meter per bird, 5 birds per treatment requires 12 sq. meter area ( $2 \mathrm{~m} \times 6 \mathrm{~m}$ cage or compartment), a total of $144 \mathrm{sq}$. meter for 60 birds. Total Confinement requires 1.0 sq. foot per bird, 5 birds per treatment requires 5 sq. feet area ( $2 \mathrm{ft}$. $\times 2.5 \mathrm{ft}$. cage), a total of 60 sq. feet for 60 birds.

\section{Preparation of the experimental diets}

Commercial feeds used in this study were produced by an agrivet supplier. Chick booster contains $22 \% \mathrm{CP}$, chick starter with $16 \% \mathrm{CP}$ and broiler finisher with $14 \% \mathrm{CP}$. The experimental broilers were fed 50 grams per bird per day with chick booster in 14 days and 75 grams per bird per day with chick starter in 14 days and 110 grams per bird per day with broiler finisher also in 7 days, with a total of 35 days growing period. The 120 heads broilers and the different experimental feeds were weighed to determine the growth performance and profitability with vermi meal supplementation in their diet raised under free range and in total confinement system in terms of body weight, feed consumption, Feed Conversion Ratio (FCR), water consumption, dressing percentage. Determined the minimum level of vermi meal for broiler growth performance, profitability of broilers in the minimum level of vermi meal, and compared the minimum level of vermi meal for broiler growth performance and profitability. Caculated the production, profitability and the Return Of Investment (ROI) of broilers based on current market price.

\section{Feeds formulation}

Formulated feeds with three levels of vermi meal were also used to produce chick booster, chick starter and broiler finisher mash. The levels of vermi meal are $2 \%$ vermi meal in $98 \%$ other ingredients, 3\% vermi meal in 97\% other ingredients and 5\% vermi meal in 95\% other ingredients. Procurement of locally available feed ingredients such as rice bran D1, ground yellow corn, copra meal, soybean meal, vermi meal, methionine, decaphose and vitamin premix were based on the quantity requirements. The diets were formulated based on the chemical composition of ingredients and broiler nutritional requirements. The feed formulation using the different ingredients were computed using Pearson Square Method and Trial and Error 
Method. The quantity of formulated feed was based on the age of broilers and the type of feeds such as Chick Booster Mash (CBM), Chick Starter Mash (CSM) and Broiler Finisher Mash (BFM). In the first two weeks, the birds were fed with formulated chick booster mash $(21.70 \% \mathrm{CP})$. On the next two weeks birds were fed with starter mash (15.90\% CP), and on the last one week they were fed with broiler finisher mash (14.10\% CP). The control birds were fed with commercial ration from day-old until end of the study. The formulated feeds were subjected for fermentation using molasses, salt and oil.

Table 1. Composition of experimental diets with the different level of vermi meal (vm) as feed during the brooding and growing stage $(\mathrm{kg})$

\begin{tabular}{cccccccccc}
\hline \multirow{2}{*}{ Feed } & \multicolumn{3}{c}{ Chick Booster } & \multicolumn{3}{c}{ Chick Starter } & \multicolumn{3}{c}{ Broiler Finisher } \\
Ingredients & $\mathbf{2 \%}$ & $\mathbf{3 \%}$ & $\mathbf{5 \%}$ & $\mathbf{2 \%}$ & $\mathbf{3 \%}$ & $\mathbf{5 \%}$ & $\mathbf{2 \%}$ & $\mathbf{3 \%}$ & $\mathbf{5 \%}$ \\
& $\mathbf{v m}$ & $\mathbf{v m}$ & $\mathbf{v m}$ & $\mathbf{v m}$ & $\mathbf{v m}$ & $\mathbf{v m}$ & $\mathbf{v m}$ & vm & vm \\
\hline Rice bran D1 & 21.14 & 21.14 & 21.14 & 33.14 & 33.14 & 33.14 & 35.34 & 35.34 & 35.34 \\
Ground yellow & 42.28 & 42.28 & 42.28 & 46.39 & 46.39 & 46.39 & 49.47 & 49.47 & 49.47 \\
corn & 10.03 & 9.50 & 8.23 & 4.12 & 3.37 & 3.28 & 2.47 & 3.02 & 1.22 \\
Copra meal & 19.20 & 18.73 & 18.00 & 9.00 & 8.75 & 6.84 & 5.37 & 3.82 & 3.62 \\
Soy bean meal & 19.00 & 2.00 & 3.00 & 5.00 & 2.00 & 3.00 & 5.00 \\
Vermi meal & 2.00 & 3.00 & 5.00 & 1.00 & 1.00 & 1.00 & 1.00 & 1.00 & 1.00 \\
Molasses & 1.00 & 1.00 & 1.00 & 1.00 & 1.00 & 1.00 \\
Oil & 1.00 & 1.00 & 1.00 & 1.00 & 1.00 & 1.00 & 1.00 & 1.00 & 0.25 \\
Salt & 0.25 & 0.25 & 0.25 & 0.25 & 0.25 & 0.25 & 0.25 & 0.25 & 0.55 \\
DL Methionine & 0.55 & 0.55 & 0.55 & 0.55 & 0.55 & 0.55 & 0.55 & 0.55 & 1.00 \\
Vitamin premix & 1.00 & 1.00 & 1.00 & 1.00 & 1.00 & 1.00 & 1.00 & 1.00 & 1.00 \\
Limestone & 0.50 & 0.50 & 0.50 & 0.50 & 0.50 & 0.50 & 0.50 & 0.50 & 0.50 \\
Dicaphos & 0.60 & 0.60 & 0.60 & 0.60 & 0.60 & 0.60 & 0.60 & 0.60 & 0.60 \\
Lysine & 0.45 & 0.45 & 0.45 & 0.45 & 0.45 & 0.45 & 0.45 & 0.45 & 0.45 \\
Total & $\mathbf{1 0 0}$ & $\mathbf{1 0 0}$ & $\mathbf{1 0 0}$ & $\mathbf{1 0 0}$ & $\mathbf{1 0 0}$ & $\mathbf{1 0 0}$ & $\mathbf{1 0 0}$ & $\mathbf{1 0 0}$ & $\mathbf{1 0 0}$ \\
\hline
\end{tabular}

\section{Feed fermentation}

After feeds formulation, it was followed with fermentation. The CBM was mixed with $0.66 \mathrm{~kg}$ molasses, $0.18 \mathrm{~kg}$ salt and $0.66 \mathrm{~kg}$ oil. CSM was mixed with $0.96 \mathrm{~kg}$ molasses, $0.24 \mathrm{~kg}$ salt and $0.96 \mathrm{~kg}$ oil. BFM was mixed with $0.72 \mathrm{~kg}$ molasses, $0.18 \mathrm{~kg}$ salt and $0.72 \mathrm{~kg}$ oil. Fermented feeds had undergone a 24- hour curing before feeding. Each type of formulated broiler feeds (CBM, CSM \& CFM) were divided in 3 levels of vermi, one (1) part contents $2 \%$ level, $3 \%$ level \& 5\% level respectively. The formulated feeds were subjected for analysis; 300 grams from every type of feeds (CBM, CSM \& CFM) per samples were collected. Each type of feed sample comprised 100 grams from formulated feeds in each level of vermi. These fermented rations had undergone analysis of Crude Protein using Automated Kjeldahl Method (Bunchi) by the Department of Science and Technology (DOST)-Food and Nutrition Research Institute Service Laboratory, Taguig, Metro Manila, Philippines.

\section{Experimental birds, design and treatments}

A total of 120 broiler chicks were used and randomly divided into two groups of management systems and four feeding treatments. The study involved eight (8) treatment combination in a 2x4 factorial experiment and distributed using Completely Randomized Design (CRD). Each management system has 60 chicks distributed to four (4) treatments and three (3) replications. Thus, each treatment replicate allotted five (5) heads of broiler chicks. 


\section{Analysis of data}

All observations in each parameter were subjected to Analysis of Variance (ANOVA) for factorial experiment in a Completely Randomised Design (CRD). The researcher also used the Statistical Tool for Agricultural Research (STAR), Plant Breeding Genetics and Biotechnology Biometrics and Breeding Informatics, Version 2.0.1 (2014) of IRRI. Treatment means were compared using Least Significance Difference (LSD) at 5\% level of significance.

\section{Results and discussion}

\section{Body weight}

The different management systems of broiler did not significantly affect its body weight in 35 days of this study (Table 2). Numerically, however, the total confinement (1,053.80 grams) had achieved the higher final weight relative to free range (1,018.20 grams) with a value of 35.60 grams difference. This could be due to the more energy consumed by the birds in roaming in the free- range area. Meanwhile, vermi levels had significantly affected the final weight of broilers 35 days after harvest both from total confinement and free range. In terms of experimental diets, commercial feeds had remarkably heavier body weight in both management systems (total confinement and free range). Indicating such in both management systems, the influence of commercial feeding had shown no difference to the body weight performance of broilers. On the other hand, comparable results were observed from different vermi levels from both management systems. It showed that $2 \%$ level of vermi meal was enough to feed the broiler because an optimum level in terms of body weight, weight gain and feed conversion ratio were already met using the aforesaid percent of application. There was no significant interaction effect observed between the two management systems and different vermi meals 35 days after harvesting. Table 2 . Body weight of broilers in 35 days as affected by different levels of vermin meal subjected to total confinement and free range.

Table 2. Body weight of broilers in 35 days as affected by different levels of vermin meal subjected to total confinement and free range

\begin{tabular}{cc}
\hline Factors & Body Weight (grams) \\
\hline Factor A. management system & \\
Total confinement & $1,053.80 \mathrm{a}$ \\
Free range & $1,018.20 \mathrm{a}$ \\
Factor B. broiler ration & $1,304.0 \mathrm{a}$ \\
A1B0 & $928.7 \mathrm{~b}$ \\
A1B1 & $1,007.3 \mathrm{~b}$ \\
A1B2 & $975.3 \mathrm{~b}$ \\
A1B3 & $1,292.0 \mathrm{a}$ \\
A2B0 & $908.7 \mathrm{~b}$ \\
A2B1 & $966.0 \mathrm{~b}$ \\
A2B3 & $956.0 \mathrm{~b}$ \\
NS & N \\
\hline
\end{tabular}

Means in a column followed by a common letter were not significantly different, based on LSD Test at $\mathrm{p}<0.05$ 


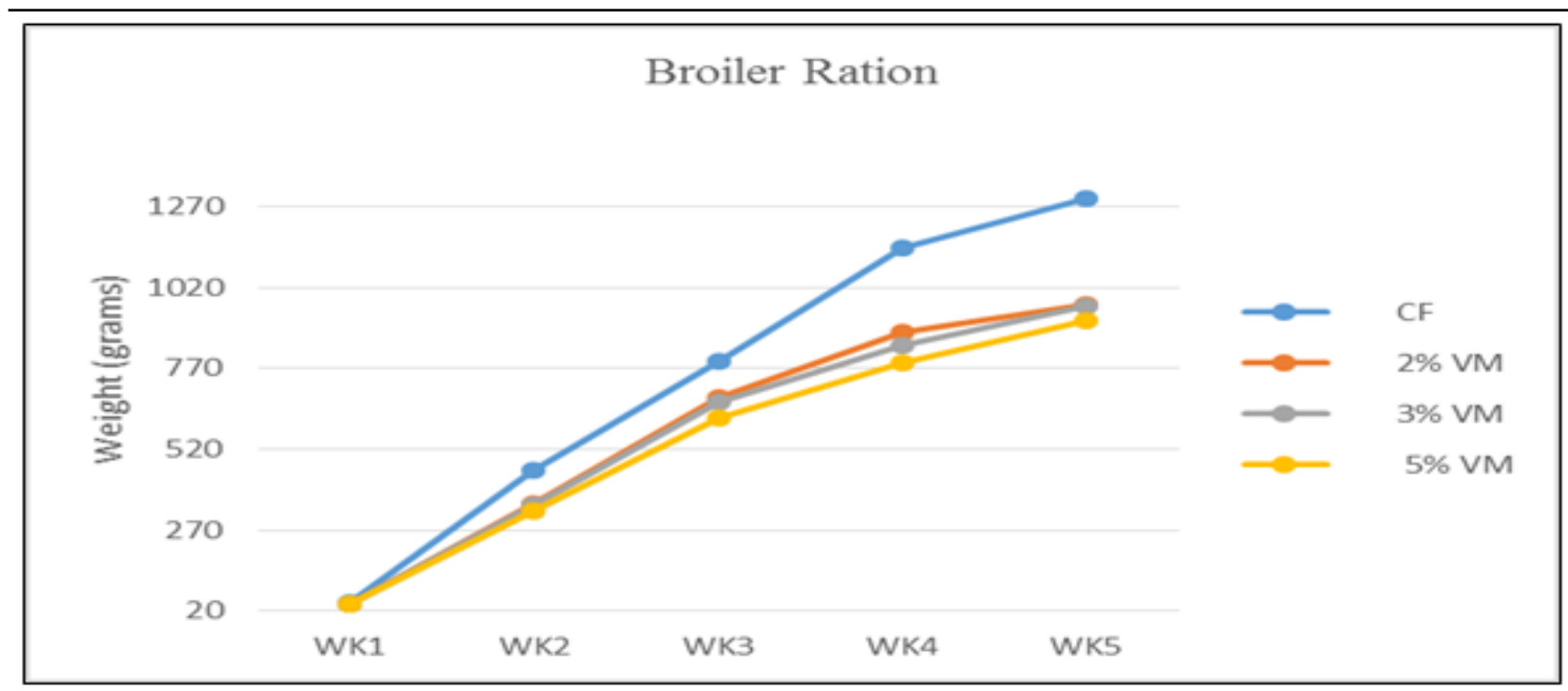

Figure 1. Average weight of broilers in different ration

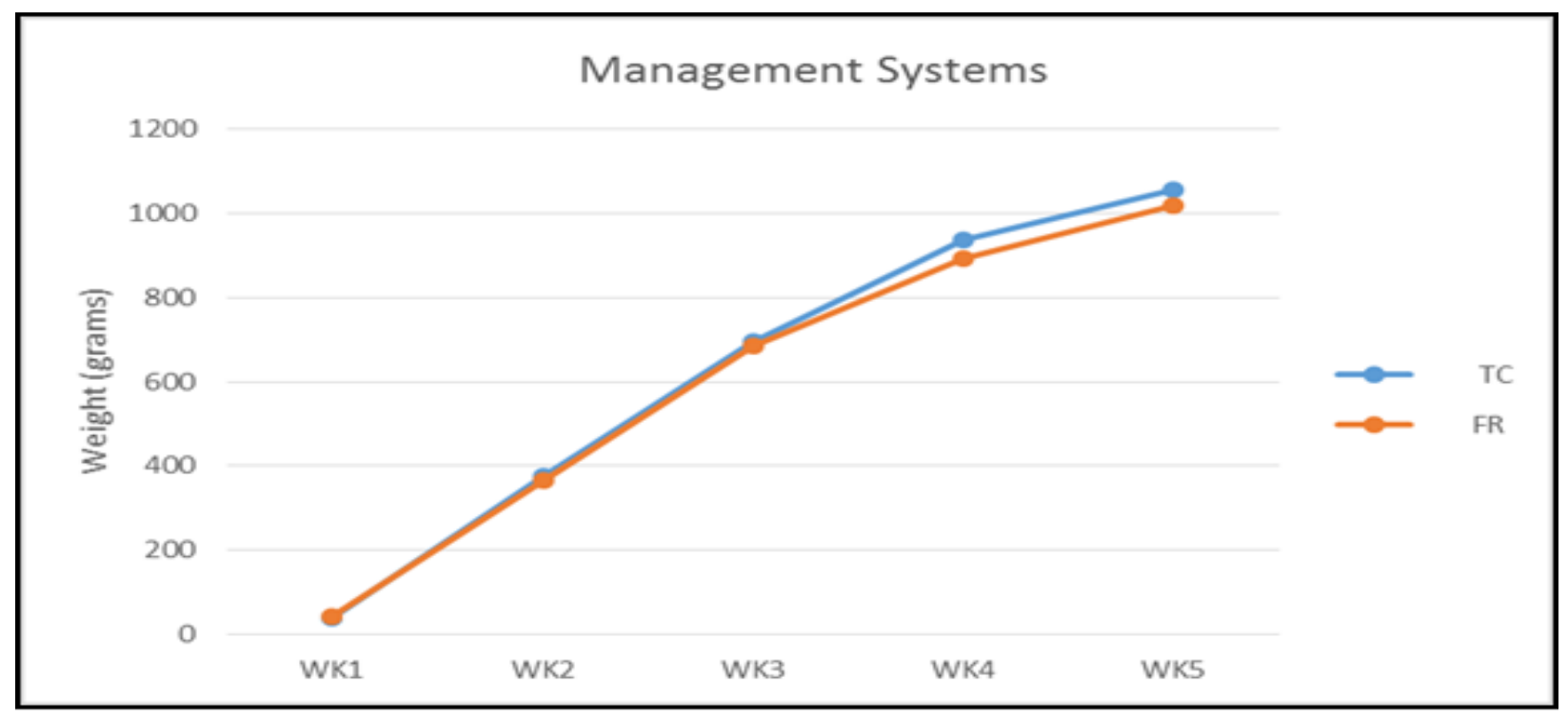

Figure 2. Average weight of broilers under two management systems

\section{Average weight gain of broiler}

The average weight gain of broiler after harvest was not significantly influenced by the management system (Table 3). However, the total confinement had numerically heavier broiler weight gain at an average difference of 36.90 grams which was consistent with the result by (Wang et al., 2009) that the body weight and weight gain of broilers in the free- range treatment were significantly lower than those chickens raised in the indoor treatment. Regardless of management system, the average weight gain of broiler after harvest was significantly affected by the different broiler ration. The commercial feeds had significantly heavier weight gain from both free range and total confinement as compared to different level of vermi meal. However, the levels of vermi meal were comparable with each other. The results showed that at increasing rate of application from $2 \%$ to $5 \%$ vermi meal, it had inversely affected the broiler weight gained to decrease further. It indicated that the $2 \%$ levels of vermi 
meal was the optimum percentage rate to be applied in broiler to attain a stable broiler production.

The interaction effect between management system and levels of vermi meal did not significantly affect the average weight gained of broiler 35 days after harvest.

Table 3. Average weight gain of broilers in 35 days as affected by different levels of vermi meal subjected to total confinement and free range

\begin{tabular}{cc}
\hline Factors & Average Weight Gain (grams) \\
\hline Factor A. management system & \\
Total confinement & $1,013.00 \mathrm{~A}$ \\
Free range & $1,254.70 \mathrm{~A}$ \\
Factor B. broiler ration & $1264.00 \mathrm{a}$ \\
A1B0 & $885.43 \mathrm{~b}$ \\
A1B1 & $967.33 \mathrm{~b}$ \\
A1B2 & $935.04 \mathrm{~b}$ \\
A1B3 & $1,245.3 \mathrm{a}$ \\
A2B1 & $868.67 \mathrm{~b}$ \\
A2B2 & $874.33 \mathrm{~b}$ \\
A2B3 & $866.00 \mathrm{~b}$ \\
NS
\end{tabular}

Means in a column followed by a common letter were not significantly different, based on LSD Test at $\mathrm{p}<0.05$

\section{Feed Consumption}

The feeds consumption of broiler was significantly influenced by the management system of broiler (Table 4). The total confinement (1,761.10 grams) had significantly higher feeds consumption relative to free range $(1,680.00$ grams). The higher feeds consumption experienced by Total Confinement (TC) in comparison with the free range was mainly due to the broilers focused on feeds ration from TC since no other source of ration was available for them to consume. Unlike, in the free range area, the birds were more exposed to other ration in which they could freely roam around from the allotted wider space to look for other source of foods and/or access to pasture with various feeds like grasses, insects, worms, minerals from soil and stones. Furthermore, (Wang et al., 2009) also revealed that free- range system of growing broiler has many advantages concerning to uncontrolled environmental factors that might influence the feeds uptake of broiler such as temperature, photoperiod, and light intensity which were inherently variable, as a result, giving the broiler with more favourable feeding condition. Meanwhile, the different vermi levels had significantly influenced the feed consumption performance of broiler. The higher feeds consumed was observed in the commercial feeds of the total confinement (A1B0) but this did not give consistent results when applied to free range (A2B0). This result might be due to the restricted condition of broiler in TC to access to other sources of foods. However, the $5 \%$ vermi meal of total confinement (A1B3) had significantly higher feeds consumption than from the rest of vermi meal treatments. This result showed that at total confinement application of vermi meal of $5 \%$ predominantly improved the feeding habit of broiler. This result was also true to the free range in which the consumption of feeds at $5 \%$ level had increased the feeds consumption of broiler. Thus, $5 \%$ level of vermi meal was the optimum level in which the birds had consumed more feed from both management system but were significantly higher in TC. This result was in 
accordance with the study on quail as reported by (Prayogi, 2011) in which the 5\% level of vermi meal consumption gave an optimum level of feeds consumption.

Table 4. Feeds consumption of broilers in 35 days as affected by different levels of vermi meal subjected to total confinement and free range

\begin{tabular}{cc}
\hline \multicolumn{1}{c}{ Factors } & Feed consumption (grams) \\
\hline Factor A. management system & $1,761.10 \mathrm{a}$ \\
Total confinement & $1,680.00 \mathrm{~b}$ \\
Free range & \\
Factor B. broiler ration & $1,845.30 \mathrm{a}$ \\
A1B0 & $1,633.30 \mathrm{~h}$ \\
A1B1 & $1,763.90 \mathrm{c}$ \\
A1B2 & $1,801.90 \mathrm{~b}$ \\
A1B3 & $1,692.50 \mathrm{e}$ \\
A2B0 & $1,649.00 \mathrm{~g}$ \\
A2B1 & $1,670.90 \mathrm{f}$ \\
A2B2 & $1,707.40 \mathrm{~d}$ \\
A2B3 & $\mathrm{S}$ \\
Interaction (A x B) &
\end{tabular}
at $\mathrm{p}<0.05$

\section{Feeds conversion ratio}

The Feeds Conversion Ratio was not significantly influenced by the management system (Table 5) as the results were comparable to each other. On the other hand, the feeds conversion ratio was significantly influenced by the different broiler ration. The $2 \%$ vermi meal (A1B1) had significantly higher feeds conversion ratio but was comparable to $3 \%$ and $5 \%$ vermi meal which was observed in total confinement. This result reflects that there was better feeds consumption in vermi meal as compared to commercial feeds from both management but in return produced lower weight gained (Table 3). This result was due to the complete availability of nutrients present in commercial feeds which satisfied the feeding habit of broiler.

Table 5. Feeds conversion ratio (FCR) of broilers in 35 days as affected by different levels of vermi meal subjected to total confinement and free range.

\begin{tabular}{cc}
\hline Factors & FCR (grams) \\
\hline Factor A. management system & \\
Total confinement & $0.20 \mathrm{a}$ \\
Free range & $0.19 \mathrm{~b}$ \\
Factor B. broiler ration & $0.16 \mathrm{c}$ \\
A1B0 & $0.23 \mathrm{a}$ \\
A1B1 & $0.21 \mathrm{ab}$ \\
A1B2 & $0.22 \mathrm{ab}$ \\
A1B3 & $0.15 \mathrm{c}$ \\
A2B0 & $0.20 \mathrm{~b}$ \\
A2B1 & $0.20 \mathrm{~b}$ \\
A2B2 & $0.20 \mathrm{~b}$ \\
A2B3 & $\mathrm{NS}$ \\
\hline
\end{tabular}

Means in a column followed by a common letter were not significantly different, based on LSD Test at $\mathrm{p}<0.05$ 


\section{Water Consumption}

The water consumption of broiler was significantly influenced by the management system of broiler (Table 6). The total confinement had significantly higher volume of water consumption relative to free range. The higher volume of water consumption influenced by the total confinement was mainly due to the broilers concentration to drink more water since they had no other supply of water to deal with. Meanwhile, in contrast of broiler in the free range, they had more access of water source coming from the rain, dew, and moist grasses. Meanwhile, the different ration of broiler had significantly influenced the water consumption of broiler. The commercial feeds in total confinement (A1B0) and 3\% vermi meal in free range (A2B2) showed a significant higher water consumption as they were comparable from each other. The higher consumption of water in A1B0 may be attributed by the higher volume of feeds consumed by broiler, as shown in Table 4 . It indicated that broiler consumption of feeds was directly proportion to the water consumption. Whereas, in different vermi meals, there was a higher volume observed in A2B2 which indicated that $3 \%$ vermi meal in a free range would make the broiler to crave more water in the feeder rather than in other water sources. There was a significant interaction between management system and different ration of broiler in which the commercial feeds in the total confinement area or vice versa had higher rate of water consumption.

Table 6. Water consumption of broilers in 35 days as affected by different levels of vermi meal subjected to total confinement and free range

\begin{tabular}{cc}
\hline Factors & Water consumption (liter) \\
\hline Factor A. management system & \\
Total confinement & $4.03 \mathrm{a}$ \\
Free range & $3.95 \mathrm{~b}$ \\
Factor B. broiler ration & \\
A1B0 & $4.23 \mathrm{a}$ \\
A1B1 & $4.00 \mathrm{~b}$ \\
A1B2 & $4.02 \mathrm{~b}$ \\
A1B3 & $3.88 \mathrm{c}$ \\
A2B0 & $3.76 \mathrm{~d}$ \\
A2B1 & $3.79 \mathrm{~d}$ \\
A2B2 & $4.21 \mathrm{a}$ \\
A2B3 & $4.04 \mathrm{~b}$ \\
$\mathrm{~S}$
\end{tabular}

Means in a column followed by a common letter were not significantly different, based on LSD Test at $\mathrm{p}<0.05$

\section{Dressing percentage}

The dressing percentage of the broiler was significantly influenced by the management system of broiler (Table 7). The total confinement had significantly higher in meat recovery which attributed to the volume of water consumption (A1) than free range (A2). This attributed that total confinement contained more moisture and fat in the meat. It was emphatically confirmed by (Boskovic et al., 2010), that free range rearing system was more favourable than extensive indoor system, as it resulted to higher protein content and a lower fat content of white and dark chicken meat. Regardless of management system, the dressing percentage of broiler was significantly influenced by the different broiler ration. The treatment of commercial feeds was significantly higher than with $2 \%$ level of vermi 
meal but was comparable with $3 \%$ and $5 \%$ level of vermi meal. However, the difference among treatments was just numerically small. The higher recovery of weight or dressing percentage of broiler in commercial feeds may be attributed by the content of fat and water of the meat as birds had higher water consumption (Table 6).

Table 7. Dressing percentage of broilers in 35 days as affected by different levels of vermi meal subjected to total confinement and free range.

\begin{tabular}{cc}
\hline Factors & Dressing percentage (grams) \\
\hline Factor A. management system & \\
Total confinement & $70.67 \mathrm{a}$ \\
Free range & $68.58 \mathrm{~b}$ \\
Factor B. Broiler ration & $71.33 \mathrm{a}$ \\
A1B0 & $70.33 \mathrm{ab}$ \\
A1B1 & $70.67 \mathrm{ab}$ \\
A1B2 & $70.33 \mathrm{ab}$ \\
A1B3 & $69.33 \mathrm{bc}$ \\
A2B0 & $68.00 \mathrm{c}$ \\
A2B1 & $68.33 \mathrm{c}$ \\
A2B2 & $68.67 \mathrm{c}$ \\
A2B & $\mathrm{NS}$ \\
\hline
\end{tabular}

Means in a column followed by a common letter were not significantly different, based on LSD Test at $\mathrm{p}<0.05$

\section{Production, profitability and return of investment}

The cost and return analysis of raising broiler were affected by the management systems and different rations (Table 8). The study revealed that the broilers in free range had $16.38 \%$ ROI which was higher compared to total confinement with $2.07 \%$. This result was seconded by the result of (Minh, 2005) which implies that free range chicken systems are sustainable and economical for both local and improved chicken breeds. Economic benefits were 12 to $36 \%$ higher compared to total confinement. In the different ration or in the different level of vermi, results showed that broilers fed with $2 \%$ vermi (B1) had higher net income and return of investment. The results could be concomitant to with the expenses in operation in both management systems. The final weight in comparison with the two management system revealed that free range produce was sold in higher price than the produce from total confinement (see Table 8).

In this study, different level of vermi meal; $2 \%, 3 \%$ \& $5 \%$ were combined to different local ingredients such as rice bran, copra meal, soybean meal, ground yellow corn and other micro ingredients. The growth of broilers in the different level of vermi meal was comparable to each other. Numerically, broilers with the $2 \%$ vermi meal had the high growth performance in both management systems. Profitability performance of broilers and the ROI showed high in $2 \%$ level of vermi meal in both management systems.

\section{Level of interaction of level meal in the diet of broilers in two management systems}

There was interaction effect between management system and different broiler ration on the feeds consumption of broiler (Table 4). The significant difference of total confinement in each different level of broiler ration was observed in the commercial feeds or vice versa. 
Table 8. Production, profitability and the return of investment of broilers in 35 days raised under two management systems and with vermi meal supplementation

\begin{tabular}{cccc}
\hline Management Systems & $\begin{array}{c}\text { Production Cost } \\
\text { (PhP) }\end{array}$ & $\begin{array}{c}\text { Profit } \\
\text { (PhP) }\end{array}$ & $\begin{array}{c}\text { Return of } \\
\text { Investment (ROI) }\end{array}$ \\
\hline Total confinement & & & \\
(TC) & & 58.25 & $2.23 \%$ \\
A1B0 (15 heads) & $2,607.00$ & 53.00 & $1.89 \%$ \\
A1B1(15 heads) & $2,804.00$ & 59.00 & $2.10 \%$ \\
A1B2 (15 heads) & $2,804.00$ & 58.00 & $2.07 \%$ \\
A1B3 (15 heads) & 2,804 & 458.25 & $16.34 \%$ \\
Free range (FR) & & 455.50 & $16.24 \%$ \\
A2B0 (15 heads) & 2,804 & 463.75 & 16.549 \\
A2B1 (15 head) & 2,804 & 459.25 & 16.38 \\
A2B2 (15 heads) & 2,804 & & \\
A2B3 (15 heads) & 2,804 & & \\
\hline
\end{tabular}

This implicitly meant that broilers in total confinement consumed feeds well when using commercial feeds as ration. On the other hand, regarding the influence of different levels of vermi meal, the significant difference of total confinement in each different level of broiler ration was observed in 5\% level of vermi meal application and vice versa. The results of interaction indicated that $5 \%$ vermi level were more preferred by the birds indicating that it attracted more birds compared to $2 \%$ and $3 \%$ vermi meal.

\section{Conclusion}

Based on the findings of the study, there were substantial conclusions that came out:

1. As a result, the vermi meal inclusion in the feed of broiler could be optimally given at $2 \%$ level since it significantly increased the broiler's final weight and gain weight, with comparable feed consumption and high Feed Conversion Ratio that of commercial feeds. Water consumption was higher in TC compared to FR, since in FR management broilers can source water from the natural habitat. In TC significantly higher meat recovery maybe attributed to the volume of water consumption (A1) than free range (A2). This attributed total confinement contained more moisture and fat in the meat. In the management aspects, the two systems were not significantly different, although numerically, the total confinement broilers had a higher final weight and weight gain.

2. In the economic aspects, study revealed that the free- range management system gathered higher in terms production performance higher net income and profitability was attained. In terms of cost and return analysis of raising broiler as affected by the management systems, different rations and total sales of the live and dressed broilers, the broilers in free range had $16.38 \%$ ROI while $2.07 \%$ only in total confinement.

3 . In the different ration or in the different level of vermi, the broilers fed with $2 \%$ vermi were profitable with higher net income.

4. Interaction effect was observed between management system and broiler ration based on feeds consumption of broiler. The significant difference on weight between treatments was observed in the commercial fed. The influence of different levels of vermi meal was observed in broiler consumption at $5 \%$ of vermi meal. 


\section{Acknowledgements}

I wish to express my heartfelt thanks and profound gratitude to individuals who have extended utmost cooperation, wholehearted support, and sincere encouragement for the completion of this humble academic endeavour: The Lord God Almighty, for the divine grace, guidance, knowledge, wisdom and strength He has bestowed upon me throughout the conduct of this study. Dr. Felix A. Afable, the Dean, professor at Eastern Samar State University, for his invaluable guidance, constructive suggestions and insightful advice that motivated me to carry out the study to successful completion. To my family, whose unconditional love and support have given me inspiration and boosted my waning spirit as I struggled for the fruition of this scholarly work.

\section{References}

Bahadori Z., Esmaylzadeh, L., Amir M., \& Torshizi K, (2015). Biological Forum - An International Journal 7, vol. 7, issue 1 pp. 998-1005

Bogosavljevic-Boskovic, S, Mitrovic, S, Djokovic, R, Doskovic, V, Djermanovic, V. (2010). Chemical composition of chicken meat produced in extensive indoor and-free-rangerearing-systems. African J. Biotechnol., 9(53):9069-9075

Elgilani, HM, (2007). The feeding value of sugar cane molasses in broiler diets. Faculty of Animal Production, University of Khartoum.

Kruchten, T. (2002). "U.S Broiler industry structure". National Agricultural Statistics Service (NASS), Agricultural Statistics Board, U.S. Department of Agriculture. Retrieved June 23, 2012

Loannis, M. (2013). Molasses in poultry diets - an unusual ingredient with potential. Retrieved from 2018, https://www.wattagnet.com/blogs/13-animal-nutritionviews/post/21718-molasses-in-poultry-diets-an-unusual-ingredient-with-potential on February 19, 2018

Minh, DV. (2005). Effect of supplementation, breed, season and location on feed intake and performance of scavenging chickens in Vietnam. Diss. (sammanfattning/summary) Uppsala: Sveriges lantbruksuniv. Acta Universit. agricult. Sueciae, 101:1652-6880.

Özhan, N, Şİmşek, ÜG, \& Özçelİk, M. (2016). Comparison of floor and cage housing systems in terms of some welfare assessments in broiler. Ankara Üniversitesi Veter. Fakü Ltesi Derg., 63(2):317-322.

Prayogi, HS. (2011). The effect of earthworm meal supplementation in the diet on quail's growth performance in attempt to replace the usage of fish meal. Int. J. Poultry Sci., 10(10):804-806. https://doi.org/10.3923/ijps.2011.804.806.

Ravindran, V, Blair, R. (1993). Feed resources for poultry production in Asia and the Pacific. III. Animal protein sources. World. Poult. Sci. J., 49(3):219-235. doi:10.1079/WPS19930020. 
Sales, J. (2014). Effects of access to pasture on performance, carcass composition, and meat quality in broilers: A meta-analysis, Poult. Sci., 93(6):15231533, https://doi.org/10.3382/ps.2013-03499.

Sogbesan, OA, Ugwumba, AAA, Madu, CT, Eze, SS, Isa, J. (2007). Culture and utilization of earthworm as animal protein supplement in the diet of heterobranchus longifilis Fingerlings. J. Fisher. Aquat. Sci., 2:375-386.Gannong, 1993.

Wang, KH, Shi, SR, Dou, TC, Sun, HJ. (2009). Effect of a free-range raising system on growth performance, carcass yield, and meat quality of slow-growing chicken. Poult. Sci., 88:22192223, https://doi.org/10.3382/ps.2008-00423.

How to cite this article: Marcos E. Bollido. Growth Performance and Profitability of Broilers with Vermi Meal on Fermented Ration Under Two Management Systems. International Journal of Advanced Biological and Biomedical Research, 2019, 7(3), 274-286. Link: http://www.ijabbr.com/article 35241.html 